\title{
Molecular cytogenetic characterization of the mouse cell line WMP2 by spectral karyotyping and multicolor banding applying murine probes
}

\author{
CONSTANZE KARST $^{1}$, VLADIMIR TRIFONOV ${ }^{1,2}$, SVETLANA A. ROMANENKO $^{1,2}$, UWE CLAUSSEN $^{1}$, \\ KRISTIN MRASEK ${ }^{1}$, SUSANNE MICHEL ${ }^{1}$, PHILIP AVNER ${ }^{3}$ and THOMAS LIEHR ${ }^{1}$ \\ ${ }^{1}$ Institute of Human Genetics and Anthropology, Kollegiengasse 10, D-07743 Jena, Germany; \\ ${ }^{2}$ Institute of Cytology and Genetics, Lavrentev Str. 10, 630090 Novosibirsk, Russia; \\ ${ }^{3}$ Unité de Génétique Moléculaire Murine, Institut Pasteur, 25 rue du Docteur Roux, 75015 Paris, France
}

Received August 31, 2005; Accepted October 28, 2005

\begin{abstract}
The Moloney murine leukemia virus-transformed suspension cell line WMP2 is derived from wild mice (Mus musculus) of the WMP/WMP strain. These mice carry nine pairs of metacentric Robertsonian translocation chromosomes. As the chromosomes of the wild-type mouse are all acrocentric, metaphase spreads of the WMP2 cells seam to be highly suited for physical gene mapping. Here we studied the WMP2 line using spectral karyotyping (SKY) combined with new established mouse specific multicolor banding (mcb) probes for the chromosomes X, 3, 4, 6 and 18. SKY revealed that the WMP2 cell line developed further four derivative chromosomes. After application of mcb five previously unrecognizable intrachromosomal rearrangements with 9 breakpoints were detected for the studied chromosomes.
\end{abstract}

\section{Introduction}

Even though Rangarajan and Weinberg in a recent study question the reliability of murine model systems in general and especially in tumor genetics, the mouse is still 'the most accessible mammalian model' (1). For cytogenetic studies the chromosomes of Mus musculus are not very popular as the 20 murine chromosome-pairs are all acrocentric and not easy to distinguish after GTG-banding. Thus, murine chromosomal rearrangements can only be characterized in detail using molecular cytogenetic approaches (see below).

Especially for physical gene mapping by fluorescence in situ hybridization (FISH) the Moloney murine leukemia virus-transformed suspension cell lines WMP1 and WMP2 turned out to be highly suited (2-9). Those two cell lines carry

Correspondence to: Dr Thomas Liehr, Institut für Humangenetik und Anthropologie, D-07740 Jena, Germany

E-mail: i8lith@mti.uni-jena.de

Key words: multicolor banding, murine cell line, WMP2, FISH, cryptic rearrangements
9 pairs of metacentric Robertsonian translocation chromosomes, including chromosomes 1-18, while the two chromosomes 19 and the sex chromosomes are the only acrocentric chromosomes (10).

The introduction of FISH using murine whole chromosome painting (wcp) probes $(11,12)$ enabled a more detailed analysis of chromosomal rearrangements in a variety of cell lines (for overview see http://mti-n.mti.uni-jena.de/ huwww/ MOL_ZYTO/mFISHlit.htm). Also the cell line WMP2 was studied by this approach previously and the present derivative chromosomes called $\mathrm{T} 1$ and $\mathrm{T} 2$ were characterized in more detail (13). However, FISH methods using wcp probes (like spectral kayotyping $=$ SKY) reach their limits, when exact localization of a chromosomal breakpoints are required or in case of intrachromosomal rearrangements such as small interstitial deletions or duplications and inversions. Thus, like previously in human cytogenetics, a FISH banding method (for review of available FISH-banding approaches see ref. 14) was developed to overcome that limitations. Here, we present a re-examination of the WMP2 cell line using spectral karyotyping (SKY) combined with mouse specific multicolor banding (mcb) probes for the chromosomes X, 3, 4, 6 and 18.

\section{Materials and methods}

Cell line WMP2 and normal mouse chromosomes. The WMP2 cell line was kindly provided by Dr H. Hameister (Ulm, Germany) and obtained via Dr M. Rocchi (Bari, Italy; http://www.biologia.uniba.it/rmc/). It was cultured as previously described at $37^{\circ} \mathrm{C}$ in RPMI medium containing $10 \%$ FCS (13). Cell harvesting and chromosome preparation were done as previously described (10). Cell suspensions of normal male and female mice were kindly provided by Dr H. Hameister (Ulm, Germany).

Generation of murine multicolor banding $(\mathrm{mcb})$ probes. The multicolor banding technique is based on overlapping region specific partial chromosome paints generated by glass-needle based microdissection (15-17). Each of the probes is based on 15-20 chromosomal fragments and the isolated DNA is amplified by DOP-PCR (18). To distinguish the human from 


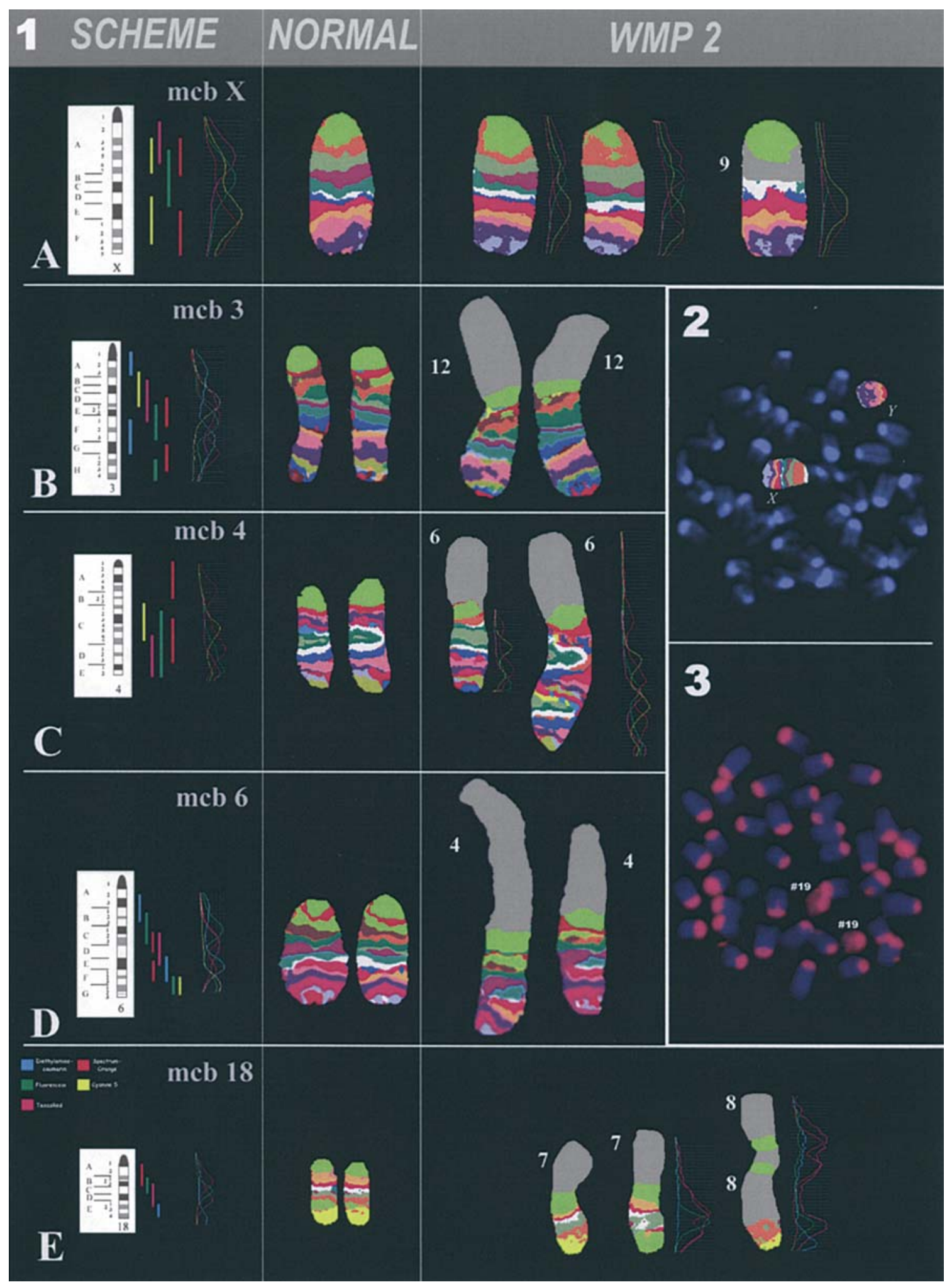

Figures 1-3. Figure 1: The five mcb libraries for the murine chromosomes $\mathrm{X}, 3,4,6$, and 18 are presented here. In the column 'SCHEME' the distribution and mode of labeling of the microdissection derived partial chromosome painting probes is depicted together with a fluorescence profile; in the column 'NORMAL' the mcb pattern on normal murine chromosome and in the column 'WMP2' the mcb pattern achieved on the WMP2 cell line are presented. The chromosomal regions pseudocolored in gray were not stained by the applied chromosome-specific mcb-probes - the information which chromosomal material was present here was obtained by comparison with the SKY results (Table I). (A) Two X chromosomes showed a normal mcb pattern, a derivative X chromosome could be described as $\operatorname{der}(9) \mathrm{t}(9 ; \mathrm{X})(? ; \mathrm{C})$. (B) No additional changes could be detected for the already known dic(3;12). (C) mcb 4 characterized a duplication, a deletion and an inversion in both two $\operatorname{dic}(4 ; 6)$ chromosomes: $\operatorname{dic}(4 ; 6)(6 \mathrm{G} 3 \rightarrow 6 \mathrm{~A} 1:: 4 \mathrm{~A} 1 \rightarrow 4 \mathrm{E} 2:: 4 \mathrm{~B} 2 \sim \mathrm{B} 3 \rightarrow 4 \mathrm{E} 2)$ and $\operatorname{dic}(4 ; 6)(6 \mathrm{G} 3 \rightarrow 6 \mathrm{~A} 1::$ 4A1 $\rightarrow$ A $3 \sim \mathrm{A} 4:: 4 \mathrm{C} 2 \rightarrow 4 \mathrm{D} 3:: 4 \mathrm{E} 2-4 \mathrm{E} 1:)$. (D) mcb 6 did not reveal any intrachromosomal changes in the two dic(4;6) chromosomes. (E) mcb 18 the confirmed the presence of two $\operatorname{dic}(7 ; 18)$ and a $\operatorname{dic}(8 ; 8) \mathrm{t}(8 ; 8 ; 18)$. The $\operatorname{dic}(8 ; 8) \mathrm{t}(8 ; 8 ; 18)$ contains only material derived from $18 \mathrm{D}$ to $18 \mathrm{E} 4$. Additionally, two different variants of the $\operatorname{dic}(7 ; 18)$ were detected: a $\operatorname{dic}(7 ; 18)$ with a normal 18 and a $\operatorname{dic}(7 ; 18)(7 ? \mathrm{~F} 4 \rightarrow 7 \mathrm{~A} 1:: 18 \mathrm{~A} 1 \rightarrow 18 \mathrm{D}:: 18 \mathrm{D} \rightarrow 18 \mathrm{~A} 2:)$. Figure 2 : Hybridization results of the mcb probe for the X chromosome on a normal male metaphase spread. Note that chromosomes X and Y are labeled. The cross-hybridization of centromeric regions is not shown. As mentioned in ref. 16 different pseudocolors can be used to illustrate the same fluorochrome profile. In this figure a different pseudocolor was applied for depiction of mcb X than in Fig 1A. Figure 3: A whole chromosome painting probe for murine chromosome 19 was created by microdissection. After application of this probe on a normal male metaphase both chromosomes 19 plus all murine centromeres are stained. 
Table I. Summary of SKY results of the present and of a previous study (13) on the WMP2 cell line.

\begin{tabular}{|c|c|c|c|c|c|c|c|c|c|c|c|c|c|c|c|c|c|c|}
\hline $\begin{array}{l}\text { Cell } \\
\text { line }\end{array}$ & $X$ & $\begin{array}{c}\text { dic } \\
(1 ; 11)\end{array}$ & $\begin{array}{c}\text { dic } \\
(2 ; 16)\end{array}$ & $\begin{array}{c}\text { dic } \\
(3 ; 12)\end{array}$ & $\begin{array}{c}\text { dic } \\
(4 ; 6)\end{array}$ & $\begin{array}{c}\text { dic } \\
(5 ; 14)\end{array}$ & $\begin{array}{c}\text { dic } \\
(7 ; 18)\end{array}$ & $\begin{array}{c}\text { dic } \\
(8 ; 8 ; 18)\end{array}$ & $\begin{array}{l}\text { dic } \\
(6 ; 9)\end{array}$ & $\begin{array}{c}\text { der } \\
(8 / 19)\end{array}$ & $\begin{array}{c}\text { der } \\
(X ; 9)\end{array}$ & $\begin{array}{c}\text { dic } \\
(10 ; 17)\end{array}$ & $\begin{array}{c}\text { dic } \\
(12 ; 12 ; 19)\end{array}$ & $\begin{array}{c}\text { dic } \\
(13 ; 15)\end{array}$ & $\begin{array}{c}\mathrm{T} 1=\text { der } \\
(13 ; 17 ; 10)\end{array}$ & $\begin{array}{c}\mathrm{T} 2=\text { der } \\
(15 ; 17)\end{array}$ & 19 & Total \\
\hline $\begin{array}{l}\text { WMP2 } \\
\text { (13) }\end{array}$ & 2 & 2 & 2 & 2 & 2 & 2 & 2 & n.a. & 2 & n.a. & n.a. & 1 & n.a. & 1 & 1 & 2 & 2 & 23 \\
\hline $\begin{array}{l}\text { Present } \\
\text { study }\end{array}$ & 2 & 3 & 1 & $1-2$ & $2-3$ & $2-3$ & $1-2$ & 1 & $1-3$ & $0-2$ & 1 & 1 & $0-1$ & $1-2$ & 1 & 1 & $0-2$ & $21-24$ \\
\hline
\end{tabular}

the murine probe sets capitals are used in the abbreviation 'MCB' in the first and lower case letters 'mcb' in the second case.

Five probe sets were created for this mcb-pilot study. For the creation of the partial chromosome paints for the chromosomes $\mathrm{X}$ and 4 , microdissection was done on metaphase spreads of the cell line WMP2. The probes were derived from the easily recognizable largest derivative chromosome and of the $\mathrm{X}$ chromosomes. Probe sets for the murine chromosomes 3, 6 and 18 were established from the cell lines SN11C5-3 sc1.3, N12C1 and SN19C8, respectively. These three mouse/ human somatic cell hybrids contain one murine chromosome each, exclusively (19). This facilitated the unambiguous recognition of the wanted murine chromosome (20).

Between 4 and 8 microdissection libraries were created per chromosome. The chromosomal location as shown in Fig. 1 is assessed by reverse painting to normal murine chromosomes. Four to five different fluorochromes are used to label the partial chromosome painting probes: SpectrumOrange, FITC, TexasRed, Cyanine 5 (= Cy5 coupled to avidin; detection of biotinylated probes) and diethylaminocoumarine (DEAC). Labeling was done by DOP-PCR, as well. All technical details of $\mathrm{MCB} / \mathrm{mcb}$ are described in Liehr et al (14). Prior to use in this study the mcb probe sets were hybridized on chromosomes of a normal male and female Mus musculus (Fig. 1).

Fluorescence in situ hybridization (FISH). Spectral karyotyping (SKY) hybridization and detection as well as the spectral analysis were done according to manufacturer's instructions. Thirty-five metaphase plates were acquired and analyzed.

Hybridization, detection and evaluation of multicolor banding (mcb) was done as previously described for human MCB (16). Ten to twenty metaphase plates were acquired and analyzed per probe set.

\section{Results and Discussion}

Here we present the first study establishing and applying murine multicolor banding (mcb) probe sets. The problem, that mouse chromosomes are hard to characterize by GTGbanding and SKY was recognized and tackled previously; i.e. at least two groups developed some kind of YAC/BAC-based chromosome bar code for mouse chromosomes (21-24). However, no further applications of these approaches were published subsequently. Thus, the easily applicable and meanwhile well-established multicolor banding technique using human probes called MCB or m-band(ing) (for over- view see http://mti-n.mti.uni-jena.de/ huwww/MOL_ZYTO/ mFISHlit.htm) was adapted for a second species the mouse (Mus musculus). Up to present the five murine chromosome specific mcb probe sets X, 3, 4, 6 and 18 were established. The establishing of the murine mcb probe sets could be done as previously described for the human ones $(16,20)$. But as the identification of the murine GTG-banded chromosomes is less reliable than in human the microdissection was performed on WMP2 (for the X chromosome and chromosome 4) and on three different mouse/human somatic cell hybrids containing exclusively the murine chromosomes 3,6 , or 18. A problem not solvable in this manner was the fact that microdissection derived probes located near or at the centromere lead, when used in FISH, to strong signals on all murine centromeres, as depicted in Fig. 3. Thus, as all mcb probe sets contain centromeric sequences, which cannot be completely blocked during the FISH procedure, all centromeres are stained automatically in parallel. Thus, both centromeres derived from chromosome 8 on the $\operatorname{dic}(8 ; 8 ; 18)$ shown in Fig. 1E are stained even though no \#8 specific probe has been applied.

All mcb probes were tested for their specify on normal male and female murine chromosomes. All probes behaved as expected apart from the mcb X: when applied to male chromosomes mcb X stained the $\mathrm{X}$ chromosome as expected but completely stained the Y chromosome, as well. Even a specific banding pattern was produced (Fig. 2). This is different from humans in which only the pseudoautosomal regions on the $\mathrm{X}$ and the $\mathrm{Y}$ are homologous to each other, probably because of similarity of heterochromatic composition of murine $\mathrm{X}$ and $\mathrm{Y}$.

The five presently available murine chromosome specific mcb probe sets $\mathrm{X}, 3,4,6$ and 18 were established and used for the further characterization of the cell line WMP2. The cell line was first tested by SKY for its integrity which led to the following (Table I). Apart from the known chromosomal aberrations (13), i.e. 10 Robertsonian translocation chromosomes, including the marker chromosome T1 plus T2 four additional clonal karyotypic changes were detected: a $\operatorname{dic}(8 ; 8) \mathrm{t}(8 ; 8 ; 18)$, a der( 8 or 19$) \mathrm{t}(8 ; 19)$, a der(9)t $(9 ; X)$ and $\mathrm{a}$ $\operatorname{dic}(12 ; 12) \mathrm{t}(12 ; 12 ; 19)$. Besides cells with derivatives of chromosome 19, still cells with two free chromosomes 19 were present. In general, a slight tendency towards polysomy of chromosomes $\mathrm{t}(1 ; 11), \mathrm{t}(5 ; 14)$ and $\mathrm{t}(4 ; 6)$ could be observed (Table I).

Thus, the WMP2 cell line had the known karyotype (13), but made a further karyotypic evolution leading to four additional derivative chromosomes. Such slight karyotypic 
changes are well-known and previously described for the cell line WMP (13) and also other cell lines (25).

Generally speaking the SKY results could be confirmed and/or refined by application of the mcb approach: a) the two $\mathrm{X}$ chromosomes showed a normal mcb pattern, the translocationchromosome including parts of the $\mathrm{X}$ chromosome could now be described as der(9)t(9;X)(?;C) (Fig. 1A); b) while mcb 6 did not reveal any intrachromosomal changes in the dic $(4 ; 6)$ (Fig. 1D) application of mcb 4 characterized a duplication, a deletion and an inversion in those two chromosomes (Fig. 1C). They can be described as $\operatorname{dic}(4 ; 6)(6 \mathrm{G} 3 \rightarrow 6 \mathrm{~A} 1:: 4 \mathrm{~A} 1 \rightarrow 4 \mathrm{E} 2::$ $4 \mathrm{~B} 2 \sim \mathrm{B} 3 \rightarrow 4 \mathrm{E} 2)$ and $\operatorname{dic}(4 ; 6)(6 \mathrm{G} 3 \rightarrow 6 \mathrm{~A} 1:: 4 \mathrm{~A} 1 \rightarrow 4 \mathrm{~A} 3 \sim \mathrm{A} 4::$ $4 \mathrm{C} 2 \rightarrow 4 \mathrm{D} 3:: 4 \mathrm{E} 2-4 \mathrm{E} 1:)$; c) applying the mcb probe set for chromosome 18 the presence of two $\operatorname{dic}(7 ; 18)$ and a $\operatorname{dic}(8 ; 8)$ $\mathrm{t}(8 ; 8 ; 18)$ was confirmed. However, there were two different variants of the $\operatorname{dic}(7 ; 18)$. One variant contained a chromosome 18 with a normal mcb pattern, while the second variant was a $\operatorname{dic}(7 ; 18)(7 ? \mathrm{~F} 4 \rightarrow 7 \mathrm{~A} 1:: 18 \mathrm{~A} 1 \rightarrow 18 \mathrm{D}:: 18 \mathrm{D} \rightarrow 18 \mathrm{~A} 2:)$. The $\operatorname{dic}(8 ; 8) \mathrm{t}(8 ; 8 ; 18)$ contains only material derived from $18 \mathrm{D}$ to 18E4 (Fig. 1E); d) no additional changes could be detected for the dic $(3 ; 12)$ (Fig. 1B).

In summary, for the $\mathrm{X}$ chromosome one translocation breakpoint (bp), for chromosome 4 one small terminal inversion ( $2 \mathrm{bp}$ ), one proximal deletion ( $2 \mathrm{bp}$ ), and a large duplication ( $2 \mathrm{bp}$ ) were detected and characterized. Furthermore, a partial inverted duplication in the $\operatorname{dic}(7 ; 18)(1 \mathrm{bp})$ and $1 \mathrm{bp}$ of a $\operatorname{dic}(8 ; 8) \mathrm{t}(8 ; 8 ; 18)$ were determined. Thus, 5 cryptic rearrangements and $9 \mathrm{bp}$ were detected by the application of mcb.

The mouse specific mcb has similar capacities as the human MCB technique. Recently we used some of the mcb libraries described here for FISH on chromosomes of golden hamster (Mesocricetus auratus), that belongs to Cricetidae family. The mcb probes labeled homology regions on hamster chromosomes, even though families Muridae and Cricetidae have diverged 20 MYA and now they comprise about 1,000 extant species. Thus, these probes can also be applied in ZOO-FISH studies as well, like the human MCB probes $(26,27)$.

In conclusion, the present study demonstrated that cryptic aberrations are easily detectable by mcb. Thus, it is likely that other, frequently used (tumor) mouse cell line also carry as yet undetected aberrations, which should be characterized in future by this very straightforward approach.

\section{Acknowledgements}

This work was supported in part by the DFG (436 RUS $17 / 49 / 02$, 436 RUS $17 / 135 / 03$ and 436 RUS 17/48/05), the Evangelische Studienwerk e.V. Villigst and the Deutsche Krebshilfe (70-3125-Li1). The cell line WMP2 was kindly provided by Dr M. Rocchi (Bari, Italy) and Dr H. Hameister (Ulm, Germany).

\section{References}

1. Rangarajan A and Weinberg RA: Opinion: comparative biology of mouse versus human cells: modelling human cancer in mice. Nat Rev Cancer 3: 52-59, 2003.
2. Said K, Jacqurt T, Montgelard C, Sonjaya H, Helal AN and Britton-Davidian J: Robertsonian house mouse population in Tunisia: a karyological and biochemical study. Genetica 68: 151-156, 1986.

3. Yachou A, Mattei MG, Roeckel N, Grandchamp B and Beaumont C: Mouse ferritin $\mathrm{H}$ sequences map to chromosomes 3, 6, and 19. Genomics 9: 204-206, 1991 .

4. Rettenberger G, Zimmermann W, Klett C, Zechner U and Hameister $\mathrm{H}$ : Mapping of murine YACs containing the genes Cea2 and Cea4 after B1-PCR amplification and FISH-analysis. Chromosome Res 3: 473-478, 1995.

5. Bleck B, Hohoff C, Binas B, Rustow B, Dixkens C, Hameister H, Borchers $\mathrm{T}$ and Spener F: Cloning and chromosomal localisation of the murine epidermal-type fatty acid binding protein gene (Fabpe). Gene 215: 123-130, 1998.

6. Paxian S, Liptay S, Adler G, Hameister H and Schmid RM: Genomic organization and chromosomal mapping of mouse nuclear factor kappa B 2 (NFKB2). Immunogenetics 49: 743-750, 1999.

7. Klein BS, Liptay S, Schmid RM and Hameister H: Assignment of Nfkbib to murine chromosome bands 7A3-B3 by in situ hybridization. Cytogenet Cell Genet 85: 308-309, 1999.

8. Klein BS, Himmelbauer H, Zechner U, Riemann M, Liptay S, Hameister $\mathrm{H}$ and Schmid RM: Assignment of the mouse Rbpsuh gene to chromosome 5 and one processed pseudogene Rbpsuhrs3 to chromosome 6. Cytogenet Cell Genet 88: 218-220, 2000 .

9. Moepps B, Vatter P, Frodl R, Waechter F, Dixkens C, Hameister $\mathrm{H}$ and Gierschik P: Alternative splicing produces transcripts encoding four variants of mouse G-protein-coupled receptor kinase 6. Genomics 60: 199-209, 1999.

10. Zörnig M, Klett C, Lovec H, Hameister H, Winking H, Adolph S and Moroy T: Establishment of permanent wild-mouse cell lines with readily identifiable marker chromosomes. Cytogenet Cell Genet 71: 37-40, 1995.

11. Liyanage M, Coleman A, Du Manoir S, Veldman T, McCormack S, Dickson RB, Barlow C, Wynshaw-Boris A, Janz S, Wienberg J, Ferguson-Smith MA, Schröck E and Ried T: Multicolour spectral karyotyping of mouse chromosomes. Nat Genet 14: 312-315, 1996.

12. Schröck E, Du Manoir S, Veldman T, Schoell VB, Wienberg J, Ferguson-Smith MA, Ning Y, Ledbetter DH, Bar-Am I, Soenksen D, Garini Y and Ried T: Multicolor spectral karyotyping of human chromosomes. Science 273: 494-497, 1996.

13. Liu G, Lu W, Bremer S, Hameister H, Schreiner B, Hughes M and Heng HH: Spectral karyotyping of mouse cell line WMP2. Cytogenet Cell Genet 90: 271-274, 2000.

14. Liehr T, Heller A, Starke H and Claussen U: FISH banding methods: applications in research and diagnostics. Expert Rev Mol Diagn 2: 217-225, 2002.

15. Chudoba I, Plesch A, Lörch T, Lemke J, Claussen U and Senger G: High resolution multicolor-banding: a new technique for refined FISH analysis of human chromosomes. Cytogenet Cell Genet 84: 156-160, 1999.

16. Liehr T, Heller A, Starke H, Rubtsov N, Trifonov V, Mrasek K, Weise A, Kuechler A and Claussen U: Microdissection based high resolution multicolor banding for all 24 human chromosomes. Int J Mol Med 9: 335-339, 2002.

17. Benedek K, Chudoba I, Klein G, Wiener F and Mai S: Rearrangements of the telomeric region of mouse chromosome 11 in Pre-B ABL/MYC cells revealed by mBANDing, spectral karyotyping, and fluorescence in situ hybridization with a subtelomeric probe. Chromosome Res 12: 777-785, 2004.

18. Telenius H, Carter NP, Bebb CE, Nordenskjold M, Ponder BA and Tunnacliffe A: Degenerate oligonucleotide-primed PCR: general amplification of target DNA by a single degenerate primer. Genomics 13: 718-725, 1992.

19. Sabile A, Poras I, Cherif D, Goodfellow P and Avner P: Isolation of monochromosomal hybrids for mouse chromosomes 3, 6, 10, 12, 14, and 18. Mamm Genome 8: 81-85, 1997.

20. Trifonov V, Karst C, Claussen U, Mrasek K, Michel S, Avner P and Liehr T: Microdissection-derived murine mcb probes from somatic cell hybrids. J Histochem Cytochem 53: 791-792, 2005.

21. Liechty MC, Carpio CM, Aytay S, Clase AC, Puschus KL, Sims KR, Davis LM and Hozier JC: Hybridization-based karyotyping of mouse chromosomes: hybridization-bands. Cytogenet Cell Genet 86: 34-38, 1999. 
22. Liechty MC, Clase AC, Puschus KL, Aytay S, Carpio CM, Hall BK and Hozier JC: Mouse linkage cytogenetics (L-C) probes. Cytogenet Cell Genet 88: 163-167, 2000.

23. Henegariu O, Dunai J, Chen XN, Korenberg JR, Ward DC and Greally JM: A triple color FISH technique for mouse chromosome identification. Mamm Genome 12: 462-465, 2001.

24. Henegariu O, Artan S, Greally JM, Chen XN, Korenberg JR, Vance GH, Stubbs L, Bray-Ward P and Ward DC: Cryptic translocation identification in human and mouse using several telomeric multiplex fish (TM-FISH) strategies. Lab Invest 81: 483-491, 2001.

25. Kuechler A, Weise A, Michel S, Schaeferhenrich A, PoolZobel BL, Claussen U and Liehr T: Precise breakpoint characterization of the colon adenocarcinoma cell line HT-29 clone $19 \mathrm{~A}$ by means of 24-color fluorescence in situ hybridization and multicolor banding. Genes Chromosomes Cancer 36: 207-210, 2003.
26. Mrasek K, Heller A, Rubtsov N, Trifonov V, Starke H, Rocchi M, Claussen $U$ and Liehr T: Reconstruction of the female Gorilla gorilla karyotype by Zoo-FISH using 25-color FISH and multicolor banding (MCB). Cytogenet Cell Genet 93: 242-248, 2001.

27. Mrasek K, Heller A, Rubtsov N, Trifonov V, Starke H, Claussen U and Liehr T: Detailed Hylobates lar karyotype defined by 25 -color FISH and multicolor banding. Int J Mol Med 12: 139-146, 2003. 